1973

\title{
Legal Implications of Biomedical Science and Technology in the Twenty-First Century
}

J.-G. Castel

Osgoode Hall Law School of York University, castel@fake.osgoode.yorku.ca

Source Publication:

Canadian Bar Review. Volume 51, Number 1 (1973), p. 119-136.

Follow this and additional works at: https://digitalcommons.osgoode.yorku.ca/scholarly_works (c) (1) $(9)$

This work is licensed under a Creative Commons Attribution-Noncommercial-No Derivative Works 4.0 License.

\section{Recommended Citation}

Castel, J.-G. "Legal Implications of Biomedical Science and Technology in the Twenty-First Century." Canadian Bar Review 51.1 (1973): 119-136.

This Article is brought to you for free and open access by the Faculty Scholarship at Osgoode Digital Commons. It has been accepted for inclusion in Articles \& Book Chapters by an authorized administrator of Osgoode Digital Commons. 
LEGAL IMPLICATIONS OF BIOMEDICAL SCIENCE AND TECHNOLOGY IN THE TWENTY-FIRST CENTURY

\author{
J.-G. CASTEL*
}

Toronto

\title{
Introduction
}

"Buy a human egg, rent a womb, shop for a super baby, grow a new heart, wake up in the year three thousand."

These advertisements might be common in the year 2000. In 1973, they would cause fear because people have not yet fully accepted the fact that biology in the last few years has developed techniques that can change not only man's environment, but man himself. This fear need not exist in the year 2000 if, within the next decades, the legal profession demonstrates that it has the capacity and the will to develop the proper responses necessary for the preservation of one of the most essential values of our society, namely, our high regard for the individual human being. Geneticists have given mankind a power so great that these responses must be adequate if our society is to survive. The rules that will evolve depend upon the ends or purposes which are sought by our society and the values which, today, we wish to preserve for tomorrow. Thus, progressive legislation and financial restraints wisely used could be powerful instruments in preventing technological abuses.

Since modern biology is frontier business, the law and the legal profession must deal with the new challenges of the continuing scientific and technological revolution. The law must be sensitive to the need for medical progress, it cannot expect to steer biomedical soience and research but it must try to hold them in bound. As biomedicine presents a wide range of legal problems for which there is no general consensus as to solutions, it is for the law to structure the compromises which man will make in adapting to the new science and the new technology."

* J.-G. Castel, of Osgoode Hall Law School, York University, Toronto.

${ }^{1}$ Selected Bibliography: Symposium on Medical Progress (1967), 32 L. \& Contemp. Prob. 561 et seq.; Symposium, Toward the Year 2000: Work in Progess (1967), 96 Daedalus 639 et seq.; A Symposium: Some Legal Problems in Medical Treatment and Research (1968), 36 Fordham 
The science of genetics has come into its own and is here to stay. With the rising expectations created by biology, increased demands will be made on the government. Biomedical advances by impinging directly on the physiology and psychology of man, create important social, ethical and legal dilemmas. Already, today, there is much greater interdependence among different disciplines. This will increase in the future. As history has taught us that it is impossible to suppress the growth of knowledge, no matter what laws are passed and no matter what stand a particular society or religion takes, legislators and the legal profession must think of the ways in which the law can respond to the exponential growth in biomedical knowledge in the next fifty years. How should lawyers and legislators react? Priorities must be established based on a pulse and temperature reading of the social group to which the laws will apply. Is our society ready to accept legislation radically at odds with prevailing values and mores? There are many policy alternatives to be considered at any given period of history. Legislation, which is not the only panacea, should not be drafted prematurely without a full awareness of the range of technical choices as otherwise it may become obstructive. Actually, in the field of biomedical science and technology, it would be a pity to freeze the existing scientific state of the art into law. Other approaches may prove to be more effective, whether they involve self-policing by the scientific community or control by the courts applying case law. However, if legislation is absolutely needed to curb abuses of technology, it should provide for review mechanisms or automatic cutoff dates.

I predict that, within the next fifty years, legislation will be concerned with removing any existing barriers to the full application of new biomedical discoveries and techniques subject to reasonable and necessary controls. This could be done by codifying a system of ethics, although it is often difficult to translate general criteria into workable guidelines in specific clinical situations. The legislator and the legal profession must learn how to cope with techniques such as organ transplants, surgery in utero, ovum and embryo implantations, clonal reproduction, cryonic suspension and behaviour control. Thus, our society. must make sure that existing forms of political decision-making are adequate to the

L. Rev. 631 et seq.; J. Malherbe, Médecine et droit moderne (1968); Symposium, Reflections on the New Biology (1968), 15 U.C.L.A. L. Rev. 267 et seq.; P. London, Behaviour Control (1st ed., 1969) (Paper 1971); A. Rosenfeld, The Second Genesis: The Coming Control of Life (1969); Symposium, Ethical Aspects of Experimentation with Human Subjects (1969), 98 Daedalus 219 et seq.; J. L. Baudouin, L'incidence de la biologie et de la médecine moderne sur le droit civil (1970), 5 Thémis 217; Hal Hellman, In the World of the Future (1971); R. Gorney, The Human Agenda (1972); M. Hamilton, ed., The New Genetics and the Future of Man (1972). 
task of using the powers given by geneticists to their best advantage. Of course, it is also possible that environmental and social catastrophes will overtake us long before some aspects of biomedical technology become a live issue.

Lawyers must study what is being done and what is being proposed in scientific research and technology. They must become aware of social goals in order to offer intelligent and constructive criticism when considering techniques in relation to these goals. By influencing the future course of biology, they will contribute to political leadership.

Only when public opinion has become sufficiently strong and informed can it be translated into generally acceptable legislation. Where are the problem areas created for society by the life sciences? The right questions must be asked and the right choices made in order to cope adequately with the challenges presented by biomedical science and technology: For the first time in history man has the potential to improve the conditions of the entire human race, or to destroy it; let the legal profession not miss this appointment with destiny.

\section{Medical Experimentation.}

Scientific research raises ethical, moral, legal and political questions as a conflict often exists between the rights of the individual and the good of society. ${ }^{2}$ For instance, what is or is not legitimate in the area of human experimentation? The basic guiding principle should be the fundamental dignity of human life itself. Where the goals and interests of lawmakers and scientists are contradictory, which should prevail? Here the ant of balancing poteritial damage against potential benefits is often difficult.

Although man cannot suppress the growth of knowledge, the government can influence the direction of scientific research through the power of the purse strings. In this connection it should be noted that a distinction must be made between science and technology, the former being concerned with knowing and the latter with using. The law with the exception of problems raised by experimentation ought primarily to deal with actions and thus technology.

Any codification of research guidelines into law would have to recognize both the moral sensitivities of the community at large and the necessity to achieve a balance between the rights of subjects and the rights of investigators. The same rules or standards need not necessarily apply to experimentation on a healthy subject for the purpose of pure research and to experimentation on a sick subject for the purpose of healing him. The

${ }^{2}$ In general see Jay Katz, Experimentation with Human Beings (1972). 
Nuremberg Code which prescribes strict standards for experimentation on human beings could be used as a guide for the legislatures and the courts. It seems to me that in the light of the pace of new scientific discoveries, it has now become imperative to define the parameters of acceptable experimentation.

Investigators will have to follow certain formal procedures which may involve the presentation of the issues and techniques to be used to a Research Assessment Board which could assess the impact of alternative courses of action and appraise the research programmes. This is quite important as once a scientific discovery has been translated into technology, it will have both short-term and long-term beneficial and detrimental consequences. A given scientific and technological development might be highly desirable in the short run although its long-term consequences might prove to be disastrous. However, research should not be blocked simply because some of its applications are potentially dangerous. It is also important to prevent the experimenter from policing his own project.

What is an informed or free consent is a question that is not devoid of difficulties. Consent certainly does not mean the same thing when the subject is under psychological duress and when he is in good health. The patient or subject should receive an adequate explanation of the project to permit him to give an intelligent consent thereto and be assured that he can withdraw from the project at any time he desires. Often informed and free consent is not possible because many subjects cannot understand the technical details of the procedures to which they are giving consent. Agreement after discussion or persuasion is not really free either as there are many subtle forms of coercion. Also, in some types of experiment, the informed consent of the subject would vitiate the experiment. In the case of genetic manipulation, how is it possible to obtain the consent of a human being not only before he is born but even before he is conceived? There is also the more fundamental question of whether a person should be allowed to consent to any experiment. Perhaps, in all cases, the law should require more than just the subject's consent. Of course, statutes could detail the essence of an informed consent, but this would not be an easy task.

Medicine which is essentially therapeutic and patient-centred must not view the patient as a subject or specimen for study and research. This raises the question of legal sanctions to deter abuses. Such an approach may be dangerous as the legal control of scientific research is also liable to abuses.

\section{Genetic Control: The New Birth Technology.}

Today genetic knowledge and techniques of genetic control, which 
include eugenics, ${ }^{3}$ genetic engineering ${ }^{4}$ and euphenics, ${ }^{5}$ are such that they make it possible to create new versions of man and to eliminate hereditary diseases. Thus, it must be decided whether man should adopt a laissez-faire attitude and let genetic changes take place from generation to generation or take over deliberate control of his own evolution.

Before any positive voluntary or compulsory programme for genetic improvement of the human race by selection and recombination of genes in existence can be adopted, a complete change of societal attitudes and values must take place. The role of the individual in our interdependent co-operative society must be reexamined. Already negative eugenics is used with a minimum restriction of freedom. This may not be the case with positive eugenics. Who is going to determine what makes a genotype ${ }^{6}$ valuable, in other words, what man shall be tomorrow, what qualities he will possess? Since human traits are the result of a genetic predisposition and its response to the environment, it must be realized that it is not possible to completely redesign individual bodies.

Any decision to be made must give primary consideration to individual rights.

Frozen semen banks are already in operation and it is probable that in the future men or women with specially desirable characteristics will leave their semen or ova for use by women interested in having one of their children. Such banks will require controls. Also, in order to prevent incest, a system of recording will have to be established although the records should not be readily available.

If the frozen semen of a husband is considered as a projection of his life for the purpose of fertilizing his wife after he is dead, the period of the rule against perpetuities will have to be reconsidered. Semen and ova banks receive the support of those who favour selective breeding. They believe that in time genetic defects will be eliminated and the number of people with "superior" qualities increased.

If through mastery of the genetic code, geneticists are able to change the genetic constitution of future generations, important

${ }^{3}$ The study and control of various possible influences as a means of improving the hereditary characteristics of a race. Negative: that concemed with prevention of mating of individuals possessing inferior or undesirable traits. Positive: that concerned with promotion of optimal mating of individuals possessing superior or desirable traits. Dorland's Illustrated Medical Dictionary (24th ed., 1965).

4 The change of undesirable genes by directed mutation.

s The treatment of genetic maladjustments on the individual during his lifetime.

- The fundamental hereditary constitution (or assortmen $\hat{\imath}$ of genes) of an individual. Dorland's Illustrated Medical Dictonary, op. cit., footnote 3. 
political decisions will have to be made. The state will have to decide whether it wishes to embark upon a programme of positive eugenics. Such a programme would affect the entire structure of society and could threaten the freedom of each individual living in that state even if an independent Eugenics Control Board were established.

Those who are opposed to positive eugenics should press for legislation recognizing the right of an individual to procreate by natural means in order to have his or her biological child. They should also ask for the repeal of compulsory sterilization laws that are already in force in some states. ${ }^{7}$

Since control over the direction of genetic changes will no doubt be extended, strict laws with criminal sanctions may have to be passed to deal with genetic manipulations. The Bill of Rights may have to be amended so as to contain a clause stating that the human germplasm ${ }^{8}$ is inviolable as the law must prevent the birth of atopogenics. ${ }^{9}$

Even if a modest programme of positive eugenics were to be adopted, would it be possible to make it effective without authoritarian methods? How could abuses be prevented? It seems to me that the barrier to genetic manipulation should be high. There is also the danger of genetic genocide by taking advantage of racial differences and weaknesses. International controls will be necessary. ${ }^{10}$

"In Canada see the Alberta Sexual Sterilization Act, R.S.A., 1970, c. 341, which provides for the compulsory sterilization of certain mentally defective persons. For an analysis of the Act see K. J. McWhirter and J. Weijer, The Alberta Sterilization Act: A Genetic Critique (1969), $16 \mathrm{U}$. of T. L. J. 424. The Government of Alberta has promised the repeal of this Act. In British Columbia see the Sexual Sterilization Act, R.S.B.C., 1960 , c. 353 .

${ }^{8}$ The reproductive and hereditary substance of individuals which is passed on from the germ cell in which an individual originates in direct continuity to the germ cells of succeeding generations. By it new individuals are produced and hereditary characters are transmitted. Dorland's Illustrated Medical Dictionary, op. cit., footnote 3 .

${ }^{9}$ The creation of the abnormal.

${ }^{10}$ Note that the 1968 International Conference on Human Rights warned that recent scientific discoveries and technological advances might endanget the rights and freedoms of individuals. The General Assembly of the United Nations at its 1968 session shared this concern and requested the Secretary-General to undertake a study of the problems relating to human rights as they arise from developments in science and technology. A preliminary report was submitted in 1970 to the General Assembly. It consisted of a summary account of studies made on the following subjects: respect for the privacy of individuals and the integrity and sovereignty of nations in the light of advances in recording and other techniques; protection of the human personality and its physical and intellectual integrity in the light of advances in biology, medicine and biochemistry; uses of electronics which might affect a person's rights and the limits which should be placed on such uses; and the balance which should be established between scientific and technological progress and the intellectual, spiritual, cultural and moral advances of humanity. The Secretary-General was asked 
The criminal law may have to be modified if it is true, as present discoveries seem to indicate, that some criminals are gene defective. Civil liability would also be affected as the appreciation of fault in the case of a gene defective tortfeasor may have to be judged by resorting to different criteria.

Genetic engineering holds many promises. For instance, when a wife is unable to conceive for want of an ovum, it could be supplied by another person. If the wife suffers obstruction of fallopean tubes, an ovum could be removed from her ovaries. This ovum would then be fertilized by her husband and inserted in the wife's womb or in that of another woman if the wife's body chemistry were capable of harming the unborn child. A human embryo could also be fertilized and developed in vitro and later on implanted in a woman's uterus to grow until delivery. Eventually, the entire gestation process could be carried out outside the body. Until that time it is quite likely that foster wombing will become a profession, often allowing a married couple to have all their children at the same time if they so desire.

What will be the effect of gestation in vitro on the family structure? Who will raise test tube babies? Who are the parents when a natural ovum or semen has not been used? Until now we could have sex without babies, in the future we will be able to have babies without sex! Can reproduction be depersonalized without people becoming dehumanized?

Surgery in utero will become quite common in order to repair a congenital defect on the foetus until the time when the proper substance will be inserted into the semen or ovum to prevent a genetic defect.

Therapeutic insemination, ovum or embryo implantations and uterine transplants will be legalized even in the case of unmarried women. Genetically a child conceived by artificial insemination is the child of its mother, but not necessarily that of her husband if she has one. In the case of uterine transplant or ovum or embryo implantations, the child may be genetically the child of its father, but not that of his wife or other woman who bore it.

The law will also have to recognize that a child who is begotten from the sperm of a person other than the husband but with his consent is legitimate. More generally, if both parents consent to any procedure to have a child, such child should be treated as theirs for all purposes. The law should no longer consider the family as a biological or genetic unit but a consensual and spiritual unit.

Finally, there is the question whether parents should have

to continue the study of these problems. Everyman's United Nations, A Summary of the Activities of the United Nations During the Five-Year Period 1966-1970 (1971), pp. 155-156. 
the right to determine the sex, size and intelligence of their offspring.

In the near future, the genetic code of any marriage license applicant will have to be determined and recorded. Depending upon his or her genetic load, he or she may be enjoined from reproducing by natural means. In some cases sterilization may be required. In other words, marriage or sexual gratification may only be allowed between people who are genetically incompatible if they accept to be sterilized. Eventually, sterility may become the rule and fertility the exception. The right to procreate should not be an absolute right when it involves a risk for the children to be born, the parents and society. To procreate is to perform a social function, therefore society should establish qualitative and quantitative forms of control.

Just as the law now recognizes certain impediments to marriage based on consanguinity, it is quite likely that "genetic load" will become a new impediment. In fact it may not be long before we have a genetic card.

By preventing the birth of defective human beings and decreasing the incidence of the factors that produce genetically caused defects, the law could stop man's biological suicide. Thus, soon, genetic counselling will be required before and after marriage.

Already, through tests performed on the developing embryo or foetus, as for example by amniocentesis, ${ }^{11}$ the prospective parents are able to ascertain whether or not their offspring will be abnormal. In the case of an abnormal offspring abortion is readily available. Very soon there will be free, convenient and universal access to abortion. With the new abortion pill almost ready for use, abortion will become the preferred method of birth control. If legalized birth control and abortion are not successful in curbing down the population explosion, it is possible that licenses will be required to beget a child. Who will get them: those who possess "superior" genes?

Still unanswered is the question of when does a life begin to have a human value. ${ }^{11 a}$ It is unlikely that the law can give us a satisfactory answer. One could also ask what are the rights of an unborn gestated in vitro. How do you obtain the consent of a foetus for the purpose of surgery in utero. In other words should the foetus be protected in all its rights in the same manner as a child after birth so that the parent has the power to give consent for the operation on behalf of the unborn? Should the law protect

${ }^{11}$ Methol whereby a sample of the ambiotic fluid surrounding an unborn child is investigated in order to find out if the cells given off by the foetus indicate genetic disorders.

${ }^{112}$ Recently the United States Supreme Court held that a foetus is not a person under the Constitution and thus has no legal right to life. 
the blastocyte ${ }^{12}$ What about criminal liability if a laboratorygrown embryo is thrown away?

Respect for human life is essentially spiritual. It does not necessarily mean the respect of any life at any cost. In improving human life, one must be prepared to sacrifice some life. A certain waste of life is necessary, which is a very small price to pay compared to the waste of life in wars or by natural selection.

Another interesting question is whether a foetus has a right not to be born, a right which the child may exercise after birth, especial$\mathrm{ly}$ if it suffers a predictable deformity and the mother's request for an abortion was denied.

\section{Clones}

Since all the information for an organism is contained in each cell of its body, it is possible to re-create an entire organism from one or more such cells. In the future, the reproduction of complete duplicates of people through the process of cloning will take place. The clone, as an asexually produced individual, is an exact genetic copy of the parent. The nucleus containing the genes of an egg cell is removed and the genetic material of the person to be copied inserted. The egg is then implanted in a human or artificial womb to grow to maturity. Cloning by producing homogeneous persons with the same gene complement may lessen the adaptability of the population. It may also render males obsolete since ova, nuclei and uteri can all be supplied by women. However, would female clones establish relationships with men when they grow up? Drone clones could be produced to undertake the dull work nobody' wants to do.

Should clonal reproduction of people be allowed and if so will clones be humans with all the usual rights? Will they be regarded as children of the parent or as the same persons as the parent?

The individual dignity of the clones may be undermined by lack of genetic distinctiveness. Also a clone could experience difficult psychological problems especially when its parent is dead as its belief in the openness of its future may be undermined.

Since identical hearts or livers or kidneys can be found only in identical twins, clonally-produced identical twins could provide interchangeable and biologically compatible spare parts for each one of them. However will the law allow the destruction of a clone copy?

Eventually, there will be clonal reconstruction of organs and limbs of individuals. Thus, the victim of an accident may have to

${ }^{12}$ An embryonic cell that has not yet become differentiated. Dorland's Illustrated Medical Dictionary, op. cit., footnote 3. 
undergo regenerative treatment in order to mitigate or reduce the extent of his damage.

\section{Cyborgs}

Perhaps, someday, human brain tissues directly coupled to electronic units will produce hybrids between machine and man. Also, apes could acquire a speech centre through the admixture of human genes.

\section{Androids}

Soon, full-size artificial men or women will be built to do certain jobs that are not highly specialized or are difficult, dangerous or otherwise not fit for human beings. Will special laws be necessary to deal with them particularly if they possess some consciousness and intelligence? It would certainly be better for society to use androids than genetically-engineered creatures.

\section{Humanoids}

In the distant future by hybridization of genes of different species it will be possible to create living creatures having the qualities of plants and animals and using light instead of food to sustain themselves.

At the present time, it is too early to pass legislation to encourage or prevent various types of genetic research. What is needed is education of the public and open and frank discussion.

Before positive eugenic control can take place in our society by evolutionary process, we will experiment with euphenics which is the treatment of genetic maladjustments on the individual during his lifetime. Euphenics on an individual basis will probably be combined with social and cultural reform on a collective basis as a method to improve mankind.

\section{The Prospects for Immortality.}

One of the main purposes of technology in the biomedical science is to postpone death by prolonging and improving life. How successful will man be with his quest for immortality?

a) Transplantation.

I shall only add a few remarks to what I have already said in the pages of this Review $w^{13}$ concerning transplants in order to take into consideration recent developments.

In a few years, much of the human organism will be replaceable. Heart transplants will become routine operations especially once the question of body rejection is solved. Eventually, trans-

${ }^{13}$ See some Legal Aspects of Human Organ Transplantation in Canada (1968), 36 Can. Bar Rev. 345 and, more recently, Transplantation, ed. by J. S. Najarian and R. L. Simmons (1972), pp. 325 et seq. 
plantation of the brain will become possible. Already, the brain of animals has been isolated from the body and kept alive after the "death" of the rest of the organism. The difficulty with brain transplants is to find donors! It might also be possible to graft a new brain if it is that of a clone. Much sooner, uterine transplants will become quite common and beneficial. A transplanted womb will allow a previously sterile woman to gestate a child from her own egg. As a result of these techniques, nice legal problems will tax the imagination of lawyers and judges. For instance, what would the result be if a left cerebral cortex with its connections were grafted onto a man whose speech has been lost from a stroke? What about a person who has his brain transplanted into a new body grown by clonal reproduction of himself? Should a man be permitted to have his brain transplanted into a female body? Who would the father be of a child begotten from the sperm of several unrelated bodies?

At the present time, a cadaver kidney transplant sharing system between Canada and the United States has been working and saving lives. Canadian and American hospitals participating in the programme supply computerized information on how many patients are waiting for kidney transplants and what kidneys are available. The salvage of organs from cadaver donors at one hospital to treat patients in other hospitals is the new trend. In the near future, a worldwide network of kidney or heart transplant data will be established. Also, it is likely that a national and international system of organ banks will be created and used widely. It will have short-term beneficial effects on health, but unpredictable long-term consequences since it will allow for the almost indefinite preservation of life through the replacement of vital organs. These banks will have to be regulated as well as the transportation of human organs across borders.

In twenty years, replacement of vital organs will be in the form of artificial devices. This will change our concept of life and death. In fact workable artificial kidneys are already in use. A plastic heart with atomic power will be ready in a few years. Biologists have also indicated that with respect to the heart, a transplant or an artificial device may no longer be necessary if new drugs or hormones were developed that would prevent any defective functioning of the alternate binding and release of calcium within the heart cells controlling contraction and relaxation.

It is safe to predict that, in about fifty years, missing limbs or defective organs will be replaced with new ones grown from a single body cell. This is the ideal technique as the clonally produced genetically identical organs will not provoke any rejection reactions, or pose difficult legal problems.

Still to be solved adequately is the problem of who gets the 
artificial or transplanted organ when several recipients need it. Do all claimants for organs that are in scarce supply have a legal right to fair and equitable treatment which would include measuring their needs against the needs of others according to established criteria? It seems to me that the decision of life or death of the potential recipient of an organ cannot be left to a committee of physicians.

Until organs can be produced, artificially or clonally, the salvaging of cadaver organs to sustain the living will involve the question of the consent of relatives in the event that the donor did not make a donation of his body or organs.

Society can ill afford to discard tissues and organs and, eventually the law will recognize that bodies must become available automatically unless, before his death, the deceased objected to removal of his organs. The need for cadaver organs is so great that the law must be changed to satisfy this need. Useful cadaver organs will be removed automatically and placed in organ banks. No power of veto will be recognized to the next of kin. In other words, if the donor neither objects nor expressly assents before his death, his organs will be removed without permission of the family.

In the case of removal of a paired organ from a live healthy donor, the law should require a higher standard of disclosure of risk than the standard for informed consent in the case of a sick person who is used for testing a new treatment.

The sale of organs will also be allowed. For instance, the sale of a paired organ by a live donor should not present any special legal problem, although it may involve some interesting tax aspects. In the case of a sale of an organ by a live donor to be removed after his death, the value of this organ may have to be included in his gross estate!

\section{b) Death.}

Biomedical advances have given physicians the power to modify the time of death. However, if the consequences of death are of great legal significance, the fact of death must necessarily be determined by medical criteria.

The availability of machines to support or replace the functions of a deceased vital organ or to re-establish the equilibrium of a disturbed physiologic system has forced the medical and legal professions to consider the establishment of guidelines for decisions as to overt termination of treatment. It is quite likely that in the near future our present ethics will be changed and that patients will not be kept alive until they become completely senile. Decisions to terminate treatment by a simple act of omission will become widely accepted, although, with the increasing reliance 
on artificial devices, deliberate acts of omission will be required and will have to be legalized. In other words, what will be needed is a legal justification for turning off a respirator or other device on a hopelessly unconscious person with irreversible widespread brain damage. The question of when should artificial maintenance of life be employed and for how long must remain a medical question.

The law will have to recognize the possibility of early removal of organs before life-sustaining machines have been turned off once it is determined that the patient cannot be saved. It will not be necessary to define the moment of death but simply to determine when it is no longer possible to restore the patient to life. This, again, is a medical question. A human being would be considered legally dead when no longer able to sustain cerebration even if he is still connected to life-saving equipment. Thus, the legal status of a person whose "life" is maintained artificially need not be considered. Of course, still to be solved is the problem of determining how long life should be prolonged in the case of incurable disease.

In the next thirty years the advances made in the development of artificial organs and the preservation of live organs will reduce the urgency of the determination of death. Until then, any redefinition of death, if necessary, would only mean advancing the legal moment of death to a point of time when the removal of organs would leave them in a perfectly useful form.

If one accepts that a person whose cerebral functions are gone is "dead", it still does not solve the legal status of a person who is clinically and biologically dead, but whose cellular degeneracy is stopped by preservation at low. temperature.

The important problem is to determine when a life ceases to have human value. In this respect, we should not place too much emphasis upon prolonging life in all circumstances.

c) Euthanasia and the Right to Die.

In the near future, a legal right to die will be recognized as it is inconsistent for our society to allow abortion and to prohibit euthanasia. In addition to withholding treatment except for sedatives and analgesics in hopeless cases which is now common practice, society will recognize giving terminal patients lethal doses of drugs whether or not they request them. This will require a change in the criminal law. On the other hand, it is unlikely that society will accept the taking of a person's life because he or she is of no value and a hindrance to society. Nor, for instance, do I think that physicians will be allowed to furnish patients who have a serious or distressing physical or mental illness but who are not terminal patients, with the means of suicide or to give them a lethal dose of drugs. 


\section{d) Cryonic Suspension.}

Cryonic suspension or low temperature anabiosis ${ }^{14}$ will preserve either a living or a dead human body by freezing or supercooling. In the United States of America, cryogenic interment $t^{15}$ of people who were clinically dead has already taken place. When it becomes possible to freeze a patient before clinical death by perfected methods which allow reanimation at will, he will be in a dormant condition, a state of suspended animation. In this way, life may be extended indefinitely as bodies cryonically suspended could be repaired and rejuvenated several centuries later.

Legislators or the courts will be forced to consider the important question of whether one must wait for the attempt to resuscitate to fail to declare the persons in suspended animation dead or to create a new legal status for such persons. In fact, a special legal status could also be recognized for people in irreversible coma. Thus, it is important to prevent embalming and autopsies in order not to jeopardize any chance of revival.

I believe that suspension is a category between life and death and that a "suspendee" or a "frozen" should have rights and obligations recognized by law. His estate and his person should be protected. Of course, some interesting legal questions will be raised with respect to insurance policies, inheritance, taxes and the rule against perpetuities, but these are not insoluble. A presumption of death after a certain fixed period may offer a solution.

The law will have to decide whether cryogenic interment operators should be allowed to freeze a patient before clinical death when his consent or that of his relatives, should he be in an irreversible coma, has been obtained.

e) Retarding the Aging Process.

Research in the science of gerontology is close to discovering the fountain of youth. Before the end of this century, methods will be found that will delay the aging process and enable people to live at least an extra fifteen useful years. This new longevity will have far-reaching effects on pension plans, insurance companies, taxation, retirement age and the proportion of the population that works. It is of great importance to prepare for such a lengthening of life if stresses of financial, social or psychological nature are to be avoided.

So far, the value placed on longevity has always assumed a range of finite limits to the length of life. Now that there is a possibility of prolonging life almost indefinitely, society should reconsider the price of longevity. Due to the tremendous cost of

${ }^{14}$ The preservation of a living or dead human body by freezing or supercooling.

${ }_{15}$ The freezing and storage of a human body after clinical death. 
prolonging life and its societal implications, important policy decisions will have to be made by the government especially as to whether it wishes to socialize this cost through public financing. From a moral point of view, it is possible that keeping human beings alive with artificial organs, cryogenic suspension, or drugs will erode our concept of human dignity.

\section{Behaviour Control and Modification of Personality.}

Today, new developments in behaviour technology make it possible to change man's personality in radical ways. Within the next twenty years it is likely that society will allow extensive use of drugs, brain surgery and monitoring equipment to prevent suffering, aggressive action and, more generally, to restrict destructive or anti-social individual behaviour. Such techniques will no doubt improve the health and happiness of people.

Behaviour control raises many questions concerning the nature of individual freedom and the civil right issue of invasion of privacy. Does each individual possess a unique mind which is his private property as well as an essential part of human dignity which must be respected as the source of personal feeling, memories, thoughts and actions?

Electrical stimulation of the brain as well as new drugs will enable man to manipulate his own moods. Doctors will implant small electronic components inside the skull and stimulate or depress, with a tiny electrical current, various centres in the brain believed to control specific emotions or responses. Such current can produce fear, friendliness or anger, pleasure or pain, hypersexuality and many other feelings. In time, electrical stimulation of the brain could become a new form of drug abuse. Radio transmitters will be implanted in human subjects to record and control behaviour.

Brain surgery also will be used extensively in order to change or control some aspects of personality. This does not exclude surgery outside the brain to alter the endocrine ${ }^{16}$ system.

Further into the future, it appears that since the nervous system is like a computer functioning by chemical mechanism, it could be programmed by a molecular code. Physio-chemical control of the brain will permit raising the performance of our cerebral functions as well as correcting the brain's pathological defects. Already, drugs and hormones have been given to patients to act on their central nervous system without physical molestation or destruction of tissue.

${ }^{16}$ System of organs whose function is to secrete into the blood or lymph a substance that has a specific effect on another organ or part. Dorland's Illustrated Medical Dictionary, op. cit., footnote 3 . 
Eventually the mind will be plugged to a computer directly. Information stored in the computer or even in someone else's nervous system will be transferred from one person to another. Inaccuracies in the storage contents of other people's learning will be erased as in the case of a magnetic tape. Thus, automatic learning will be possible by feeding signals directly into specific neuronal structures without conscious participation. Television screens will no longer be necessary if scientists can discover the electro-chemical code that converts light rays into visual sensations in the brain. Chemistry will also augment mental powers such as memory and learning. The enlargement of human intelligence will no doubt bring about important political and social changes, as, even today, society is not able to make use of all highly educated people.

In order to prevent abuses, the law will have to recognize that there is a right to personality that is inviolable and devise mechanisms for the control of these new techniques. Should operations that alter the personality be prohibited? Perhaps such operations should be attempted only in the case of a patient who is a threat to himself or to others and after psychiatry, shock treatment and drugs have failed to help him.

What about mass mind or brain experimentation? In the case of brain implant techniques, it will be difficult to prevent their use to treat severe mental illness especially in the case of chronic offenders. In fact, this may lead to electronic policing of the brain of all offenders as well as political dissenters or nonconformists. The obvious advantage and positive aspect of these techniques is that prisons will no longer be necessary: everyone will love his neighbour! The aversion therapy used with Alex, the savage anti-hero of Clockwork Orange, may also some day become a reality.

To alleviate our legitimate fear of possible abuses, Dr. Delgado makes it clear ${ }^{17}$ that although it is possible to regulate the aggressiveness of a single individual, it would be impossible to control an entire population. Because of anatomical differences, it would be difficult to produce the same effect in all people. It is also unlikely that an individual's political ideology or national loyalty could be modified. Electrical stimulation does not bring automatic responses, but responses that are integrated with the individual's personality and social environment. In other words, a complete change in personality is, at the present time, beyond the practical potential of electrical stimulation of the brain. Someday, however, each person could be specially programmed.

${ }^{17}$ Physical Control of the Mind: Toward a Psychocivilized Society (1st ed., 1969). 
Obviously, the law should prohibit anyone or any government from seeking to control for selfish or political purposes the thoughts or behaviour of other people. Electronic coercion as a chief instrument of behaviour control through scientific manipulation of the mind must be rejected on a collective basis. However, it is not at all certain that our democratic society will resist widespread resort to behaviour manipulation techniques once they are used in individual cases.

Destructive brain surgery performed against the wishes of the patient clearly violates his civil rights. But what about behaviour control through other methods? Is a human being born free with the right to develop his own mind the way he wishes without interference from his parents, the school which he attends or the society in which he lives? In other words, should personal development follow natural tendencies without being inhibited or indoctrinated by artificial codes of conduct? In practice, it is difficult if not impossible to prevent this kind of behaviour control. Physiologically, we are not born free because of heredity and environmental information. All we can hope for is, eventually, to achieve some freedom to direct our own destiny. A child has little freedom in the way in which it develops its own mind since its brain will store the experiences provided by the environment. The formation of the mind requires cultural input. Also because man lives in society he is not entitled to complete independence in his behaviour. The question is how far should behavioural engineering, in the form of education, moral discourse or persuasion, be used. Why should persuasion by input into a person's brain through electrical stimulation present legal issues of a different nature than if such persuasion took the form of schooling or religious education?

Behaviour technology will erode freedom when it takes place by decision of anyone other than the person on whom it is used. Yet it must be recognized that in some cases, by necessity, this decision must be made by other people. The compulsory use of drugs that force an individual to reveal the truth should be prohibited. It could also be argued that a physician should not be allowed to administer treatment that will radically alter a patient's behaviour or personality even if he requested it.

How can society use behaviour control techniques to restrain anti-social actions without dehumanization or tyranny? This is a question which must be answered now.

\section{Conclusion}

In concluding, I should like to emphasize that what will ultimately be done with scientific discoveries depends upon the conscience 
of men as "science without conscience is the ruin of the soul". ${ }^{18}$ Will the new technology be accepted by our society? In some respects, this is a political problem more than a legal one. As lawyers and as human beings, we must, along with others, help give society "more soul"19 which is so needed today. We must change the conscience of man in order to make sure that science and technology cannot be abused. New developments in the biomedical science and technology are not a danger to society, it is in the way in which they are used that lies the danger. What we need is not less science and technology, but better science and technology and in this connection the legal profession has an important role to play.

${ }^{18}$ Rabelais, Gargantua et Pantagruel (1534), Book II, Ch. VIII.

19 "Supplément d'âme", Bergson, Les deux sources de la morale et de la religion (8th ed., 1946, Les Presses Universitaires), p. 329. 